\title{
MODELING OF THE THERMAL LOADS AND ENERGY CONSERVATION IN HYDRPONICS SPROUTS PRODUCTION SYSTEMS
}

\author{
Khaled k. Hegab*
}

\begin{abstract}
Sprouting green fodder production systems (SGFPS) are considered highly condensed agro-industrial systems in terms of electric energy consumption. Therefore, price rising or scarcity of electric energy of the traditional source "Public Network of Electricity" constitutes critical issue in the SGFPS management. Additionally, engineering criteria to determine the technical specifications of suitable electric solar system (ESS) as an alternative source of energy are not found. Therefore, the research main objectives were to construct mathematical model, to determine the thermal loads, to determine the best alternatives of energy conservation, and to develop an engineering criteria to specify suitable ESS. To execute these objectives a mathematical model was constructed and used in the determination of type and quantity of the thermal loads. Statistical trial was designed and executed to determine the best alternative for energy conservation. Engineering criteria were developed to determine the technical specifications of the ESS. The results showed that: The mathematical model is valid to use. The thermal equilibrium is going for cooling direction. The cooling loads are located between 5915.3 and $7739.9 \mathrm{BTU} / \mathrm{h}$. The thermal properties of the building materials are responsible on saving $65 \%$ of the thermal loads. Operations management is responsible on saving 35\% of the thermal loads, and the engineering criteria should be effective in order to determine the technical specifications of the electric solar energy source to reduce the reliance on conventional source "Public Network of Electricity" (PNE).
\end{abstract}

Keywords: Mathematical modelling - thermal loads - materials thermal properties - thermal emissions coefficients - operations management energy conservation - engineering criteria - electric solar system.

*Agric. Eng. Dept., Faculty of Agric., Cairo University, Egypt. 


\section{1- INTRODUCTION}

Production systems of hydroponics sprouted green fodder are considered closed agro-industrial systems. These systems consume a great amount of energy through washing, socking, cultivation, lighting, ventilation, irrigation, fertigation, cooling, and heating subsystems. Due to decreasing supply and increasing demand on energy, the energy price is continuously going up. Therefore, conservation of utilized energy in the sprouted green fodder production is considered critical issue. As a result, the main objective of this research was to minimize the consumed energy with keeping on quality and quantity of the sprouted green fodder production. To achieve this objective, construction of a mathematical model for determining the utilized energy in sprouted green fodder production is needed. The sprouted green fodder production chambers are constructed as part of residetional buildings or a type of greenhouses. Therefore, all equations of energy balance in the residetional buildings and the greenhouses could be used as a guide in the construction processes of the energy model.

Energy sources constitute one of the most important factors in wealth generation, economic growth and social development, therefore design and material selection of walls, roofs, ground floors and windows are considered critical issues in energy saving, Onwuka, O. 2013. Discouraging of energy consumption in the agricultural sector might increase costs of production activities. At the same time, it minimizes the environmental impact due to reduction of GHGs emissions, Kempen and Kraenzlein 2008.

The consumed energy for providing fresh water and cooling the environment of greenhouse constitute a critical issue. This energy could be generated by a sustainable greenhouse system SGH if a computational model was constructed for aiding in the SGH design and determine its limitations, Farrell et al. 2017. Significant investments on water and energy are required to limit the negative effects of drought on crop yield, Zhang et al. 2017. The agricultural residues are utilized to produce electricity and solid, gaseous and liquid biofuels through bioenergy 
technologies, Song et al. 2015. A control method of greenhouse heating using computational fluid dynamics (CFD) and energy prediction model (EPM) is used to reduce the energy consumption of agricultural greenhouses, Chen et al. 2015. The most effective opportunity for energy conservation in greenhouses is the "Double thermal screen" and "Double glazing" which gives 60\% reduction in energy demand, Vadiee and Martin 2014. Saving energy in greenhouses is an important issue for growers. Optimal control techniques can be used to minimize energy input for heating, cooling, ventilating, and the injection of industrial CO2, Van Beveren et al. 2015a. Using the delivered heat, $\mathrm{CO} 2$, and rain water from the building in rooftop greenhouse could save $341.93 \mathrm{kWh} / \mathrm{m} 2 / \mathrm{yr}$, Nadal et al. 2017.

Using a dynamic photovoltaic (PV) generates " $(102 \mathrm{~W} / \mathrm{m} 2)$ at shading percentage (78\%)" of electric energy which could be used in greenhouse operations management, Marucci and Cappuccini 2016. The estimated total energy input and energy productivity for greenhouse cucumber production were estimated as $148836.76 \mathrm{MJ}$ ha-1 and $0.80 \mathrm{~kg} \mathrm{MJ}-1$ respectively, Mohammadi and Omid 2010. The performance of the heat pump for maintaining the greenhouse air at a day temperature of $27^{\circ} \mathrm{C}$ and night temperature of $18{ }^{\circ} \mathrm{C}$ with a relative humidity of $40 \%$ spans $1.2-4.0$ and 1000 $16,000 \mathrm{~kJ} / \mathrm{kg}$ for the Coefficient of Performance (COP) and the Specific Energy Consumption (SEC), respectively, Chou et al. 2004. A dynamic optimization system based on optimal control theory was designed for saving energy and maintaining air temperature, and fixing relative humidity inside a modern rose greenhouse, Van Beveren et al. 2015b.

The calculation processes of the overall energy balance in flower greenhouses include the balances of heating, radioactive and energy required to sweat, evaporation, sensible heat of air and soil as well as the stored energy in the assimilates formation process through photosynthesis processes, Ciprian, and Brătucu 2014. Greenhouse energy balance includes soil surface energy balance, interior air energy balance, and energy balance of the cover, Mesmoudi et al. 2010. The heating and cooling Heating Ventilating and Air Conditioning (HVAC) system in combination 
with shading of glazing surfaces, controlling windows opening, and forcing convection of external air constitute an innovative plant solution for energy saving in greenhouses, Priarone et al. 2017. For energy conservation, simulation model was developed to design new buildings ensuring reduction of consumed energy in heating, cooling, lighting and ventilation process, Andarini 2014. Adoption of the net zero energy balance "using an on-site renewable energy source" for heating, domestic hot water, and ventilation in new building is considered an effective way for saving energy, Hall et al. 2014.

Nearly Zero Energy Buildings (ZEB) will be one of the main directions for minimizing energy consumption in Europe starting from the end of 2020. 'Nearly ZEB' can be achieved by both the maximization of energy efficiency and by using renewable energy sources, Scognamiglio and Røstvik 2012. Saving energy could be executed through the use of semitransparent photovoltaics (STPV) greenhouse system covered with STPV cladding material to transmit daylight, provide some shading and generate solar electricity, Bambara and Athienitis 2015. Biogas production provide climate-neutral methane gas, which is used as energy source in the hydroponics systems, Morken et al. 2015. Leadership in Energy and Environmental Design (LEED) green building certification label is a tool for saving energy and environmental conservation, Scofield 2013. Energy saving needs to take measures for replacing electric heaters with gas boilers, replacing screw chillers with centrifugal chillers, and using energysaving lamps, Wang et al. 2016.

Ground surface temperature in Egypt ranges from 18.36 to 19.38 0C which depends on soil depth, Serageeldin et al. 2015. Heating load and cooling load expressions are related to the amount of energy "heat" that would need to be added to or removed for maintaining the room temperature at an acceptable level, Burdick, A. 2011, Yadav et al. 2.17 and Cheng et al. 2018.

\section{2-MATERIALS AND METHODS}

2-1-Trail Design: Complete randomize block design trial with six treatments were statistically designed, table (1). Three shifts for servicing and two systems for cultivating were applied in the trial to study the 
consumed energy. Grains washing, soaking, composting and cultivation, sprouting follow up and green fodder harvesting were applied in three shifts which were as follows (8ap-4pm, 4pm-12pm, and 12pm-8am) respectively. Soilless culture and agricultural residues media (rice straw) were used as cultivation media. Treatment number one was used as control for statistical analysis processes.

Copper's nutrients solution with concentration of $2000 \mathrm{ppm}$ was used, Trejo-Téllez and Gómez-Merino 2012. Air temperature and relative humidity were automatically fixed inside the utilized hydroponics green fodder chamber within $20 \mathrm{C}^{0}$ and $75 \%$ respectively, Hegab 2018a. Irrigation scheduled were fixed at 60, 45 and 30 second per 6 hours the first 4 days, the second 4 days, and the third 4 days of the growth cycle respectively, Hegab 2018b. Intensity of light $\left(3600 \mathrm{~lm} / \mathrm{m}^{2}\right)$ through 12/h.day (in exception of the first three days) was used, Hegab 2018c.

\section{Table 1: Energy balance trial design:}

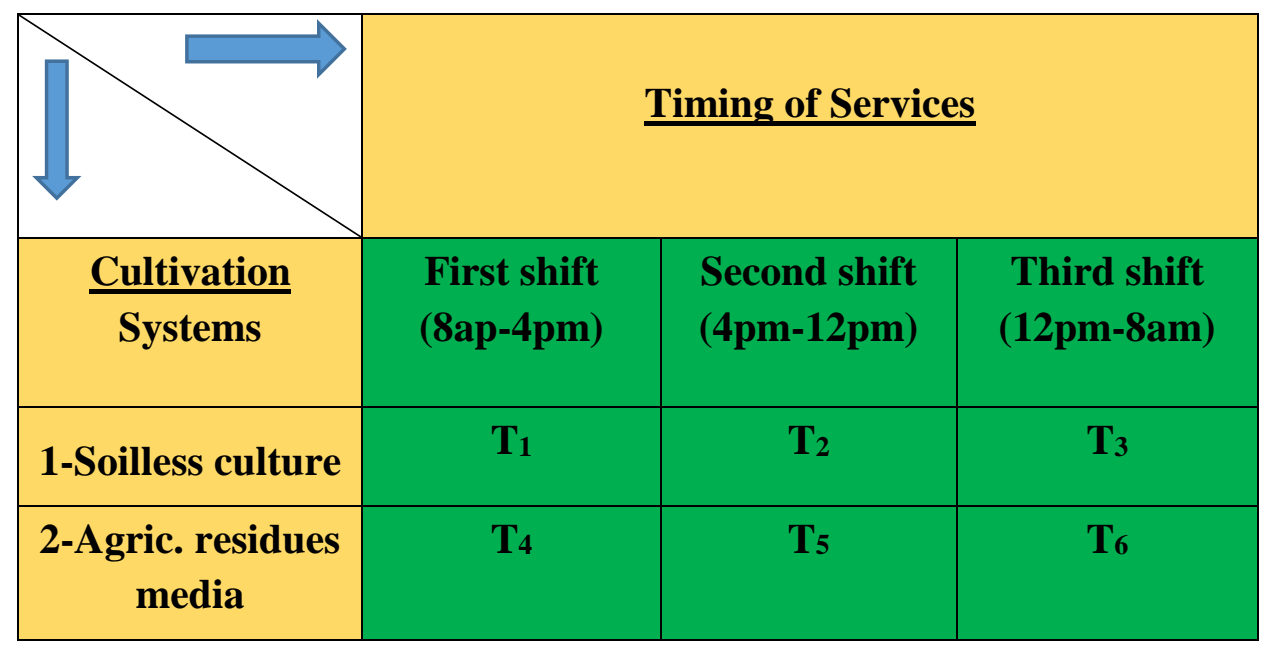

To study energy balance, thicknesses, external and internal temperature ( $T_{\text {in }}$

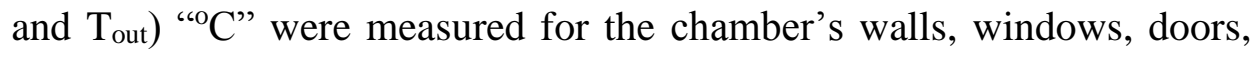
ground and roof. Additionally, standard values of technical factors and coefficients were used to complete the energy calculation processes. Consumed energy (CE) "J" were mathematically calculated and 
statistically analyzed for the six treatments. The technical criteria of the sprouted green fodder were laboratory measured and statistically analyzed Hegab 2018c.

\section{2-2-Mathematical Model Construction:}

$$
M_{a} C_{a} \frac{d T_{t}}{d t}=\sum Q_{\text {gain }}-\sum Q_{\text {loss }}
$$

where: $M_{a}$ is isothermal math of air $(\mathrm{kg}), C_{a}$ is specific heat of air $\left(\mathrm{J} / \mathrm{kg} \cdot{ }^{\mathrm{O}} \mathrm{C}\right)$, $T_{t}$ is the chamber temperature $\left({ }^{\mathrm{O}} \mathrm{C}\right), t$ is time (second), $\mathrm{Q}_{\text {gain }}$ is thermal energy gains inside the chamber (J/s), $Q_{\text {loss }}$ is thermal energy lost to the surrounding by air (J/s), Icorpora et al. 2007.

Mathematically, the thermal energy balance inside the chamber could be executed when $d T_{t}$ is equal to zero. Therefore, the value of thermal energy gain and the value of thermal energy lost are equals as follows:

$$
\sum Q_{\text {gain }}=\sum Q_{\text {loss }}
$$

In summer season or hot countries, average of the outside air temperature is greater than the inside air temperature. Therefore, the accumulation of energy and increasing air temperature inside the chamber are remarked. Irreversibly, in winter season or cold countries, average of the outside air temperature is less than the inside air temperature on average. Therefore, the losses of energy and decreasing air temperature inside the chamber are remarked. Mathematically, the equation of energy balance inside the chamber could be expressed as follows:

$$
\begin{gathered}
\sum Q_{\text {gain }}=Q_{\text {walls }}+Q_{\text {windows }}+Q_{\text {doors }}+Q_{\text {roof }}+Q_{\text {groung }}+Q_{\text {groundedgs }} \\
+Q_{\text {lobors }}+Q_{\text {ventilation }}+Q_{\text {light }}+Q_{\text {irrigation }}+Q_{\text {socking }}+Q_{\text {harvesting }}+Q_{\text {shem }} \\
Q_{\text {walls }}=\frac{\left(t_{\text {owa }}-t_{\text {iwa }}\right)\left(A_{\text {wa }}\right)}{\frac{1}{h_{\text {owa }}}+\sum_{j w a=1}^{l} \frac{b_{j w a}}{k_{\text {iwa }}}+\frac{1}{h_{\text {iwa }}}}
\end{gathered}
$$

where: $\boldsymbol{Q}_{\text {walls }}$ energy gains through the chamber's walls (w) or $(\mathrm{J} / \mathrm{s}), t_{\text {owa }}$ is air temperature outside the wall $\left({ }^{\circ} \mathrm{C}\right), t_{i w a}$ is air temperature inside the wall 
$\left({ }^{\circ} \mathrm{C}\right), A_{w a}$ is the total area of the wall $\left(\mathrm{m}^{2}\right), h_{\text {owa }}$ is the outside convection heat transfer coefficient $\left(\mathrm{W} / \mathrm{m}^{2} . \mathrm{k}\right), b_{\text {jwa }}$ is the thickness of the layer No. $\mathrm{j}$ in the wall (m), and $k_{j w a}$ is the thermal conductivity of the layer No. $\mathrm{j}$ in the wall (W/m.k), and ( $\mathrm{h}_{\text {iwa }}$ ) is the inside convection heat transfer coefficient $\left(\mathrm{W} / \mathrm{m}^{2} . \mathrm{k}\right)$, Icorpora et al. 2007, Ciprian and Brătucu 2014, Mesmoudi et al. 2010.

$$
Q_{\text {windows }}=\frac{\left(t_{o w i}-t_{i w i}\right)\left(A_{w i}\right)}{\frac{1}{h_{o w i}}+\sum_{j w i=1}^{m} \frac{b_{j w i}}{k_{i w i}}+\frac{1}{h_{i w i}}}
$$

where: $\boldsymbol{Q}_{\text {windows }}$ energy gains through the chamber's windows(w) or $(\mathrm{J} / \mathrm{s})$, $t_{\text {owj }}$ is air temperature outside the window $\left({ }^{\circ} \mathrm{C}\right)$, $\mathrm{t}_{\mathrm{iwj}}$ is air temperature inside the window $\left({ }^{\circ} \mathrm{C}\right), A_{w i}$ is total area of windows $\left(\mathrm{m}^{2}\right), h_{\text {owi }}$ is the outside convection heat transfer coefficient $\left(\mathrm{W} / \mathrm{m}^{2} . \mathrm{k}\right), b_{\text {owa }}$ is the thickness of the layer No. $\mathrm{j}$ in the window $\mathrm{m}, k_{j w a}$ is the thermal conductivity of the layer No. $\mathrm{j}$ in the window (W/m.k) and $h_{\text {iwi }}$ is the inside convection heat transfer coefficient $\left(\mathrm{W} / \mathrm{m}^{2} . \mathrm{k}\right)$, Icorpora et al. 2007, Wang 2016.

$$
Q_{d o o r s}=\frac{\left(t_{o d o}-t_{i d o}\right)\left(A_{d o}\right)}{\frac{1}{h_{o d o}}+\sum_{j d o=1}^{l} \frac{b_{j d o}}{k_{i d o}}+\frac{1}{h_{i d o}}}
$$

where: $\boldsymbol{Q}_{\text {doors }}$ energy gains through the chamber's doors(w) or $(\mathrm{J} / \mathrm{s}), t_{\text {awj }}$ is air temperature outside the door $\left({ }^{\circ} \mathrm{C}\right), t_{i d o}$ is air temperature inside the window $\left({ }^{\circ} \mathrm{C}\right), A_{w i}$ is area of doors $\left(\mathrm{m}^{2}\right), h_{o d o}$ is the outside convection heat transfer coefficient $\left(\mathrm{W} / \mathrm{m}^{2} . \mathrm{k}\right), b_{\text {ido }}$ is the thickness of the layer No. $\mathrm{j}$ in the door $\mathrm{m}, k_{j d o}$ is the thermal conductivity of the layer No. $\mathrm{j}$ in the door (W/m.k) and $h_{\text {ido }}$ is the outside convection heat transfer coefficient (W/m².k), Icorpora et al. 2007, Bambara and Athienitis 2015.

$$
Q_{\text {roof }}=\frac{\left(t_{\text {aro }}-t_{\text {iro }}\right)\left(A_{r o}\right)}{\frac{1}{h_{\text {oro }}}+\sum_{j r o=1}^{o} \frac{b_{\text {jro }}}{k_{\text {jro }}}+\frac{1}{h_{\text {iro }}}}
$$

where: $\mathbf{Q}_{\text {roof }}$ energy gains through the chamber's $\operatorname{roof}(\mathrm{w})$ or $(\mathrm{J} / \mathrm{s}), t_{\text {aro }}$ is air temperature outside the roof $\left({ }^{\circ} \mathrm{C}\right), t_{i d o}$ is air temperature inside the roof $\left({ }^{\circ} \mathrm{C}\right)$, 
$A_{w i}$ is area of roof $\left(\mathrm{m}^{2}\right), h_{\text {oro }}$ is the outside convection heat transfer coefficient $\left(\mathrm{W} / \mathrm{m}^{2} . \mathrm{k}\right), b_{\text {iro }}$ is the thickness of the layer No. $\mathrm{j}$ in the roof $(\mathrm{m})$, $k_{j r o}$ is the thermal conductivity of the layer No. $\mathrm{j}$ in the roof $(\mathrm{W} / \mathrm{m} . \mathrm{k})$ and $h_{\text {iro }}$ is the inside convection heat transfer coefficient $\left(\mathrm{W} / \mathrm{m}^{2} . \mathrm{k}\right)$, Icorpora et al. 2007.

$$
Q_{\text {ground }}=\frac{\left(t_{\text {agro }}-t_{\text {igro }}\right)\left(A_{\text {gro }}\right)}{\frac{1}{h_{\text {ogro }}}+\sum_{\text {jgro }=1}^{o} \frac{b_{\text {jgro }}}{k_{\text {jgro }}}+\frac{1}{h_{\text {igro }}}}
$$

where: $\boldsymbol{Q}_{\text {ground }}$ energy gains through the chamber's ground (w) or (J/s), tagro is air temperature outside the ground $\left({ }^{\circ} \mathrm{C}\right), t_{\text {igro }}$ is air temperature inside the ground $\left({ }^{\circ} \mathrm{C}\right), A_{\text {gro }}$ is area of ground $\left(\mathrm{m}^{2}\right), h_{\text {ogro }}$ is the outside convection heat transfer coefficient $\left(\mathrm{W} / \mathrm{m}^{2} . \mathrm{k}\right), b_{\text {igro }}$ is the thickness of the layer No. $\mathrm{j}$ in the roof $(\mathrm{m}), k_{\text {jgro }}$ is the thermal conductivity of the layer No. $\mathrm{j}$ in the roof (W/m.k) and $h_{\text {igro }}$ is the inside convection heat transfer coefficient (W/m².k), Icorpora et al. 2007.

$$
Q_{\text {linear }}=\left(l_{g r}\right)\left(\Psi_{g r}\right)\left(t_{\text {ogr }-} t_{i g r}\right)
$$

where: $\mathbf{Q}_{\text {linear }}$ linear energy gains $(\mathrm{w})$ or $(\mathrm{J} / \mathrm{s}), l_{g r}$ is length of the intersection line (m), $\Psi_{g r}$ is the linear head losses through the ground (W/m.k), $t_{o g r}$ is air temperature outside the chamber $\left({ }^{\circ} \mathrm{C}\right)$, and $t_{i g r}$ is air temperature inside the chamber $\left({ }^{\circ} \mathrm{C}\right)$, Barbosa et al. 2015, Ahmad et al. 2010.

$$
Q_{\text {labors }}=(500 / 2.16)(L N)(W R)
$$

where: $\mathbf{Q}_{\text {labors }}$ energy gains from labors activities (w) or $(\mathrm{J} / \mathrm{s})$, and $L N$ is labor number inside the chamber (w), and WR working rate (hour/day).

$$
Q_{\text {ventilation }}=\frac{\left(A C H_{a}\right)\left(V_{a}\right)}{3600}\left(C_{a}\right)\left(\rho_{a}\right)\left(t_{\text {oa- }} t_{i a}\right)(1-\eta)
$$

where: $\boldsymbol{Q}_{\text {ventilation }}$ energy gains through the chamber ventilation (w) or (J/s), $A C H_{a}$ is chamber air change per hour, $V_{a}$ is volume of chamber $\left(\mathrm{m}^{3}\right), C_{a}$ is specific density of air $\left(\mathrm{kg} / \mathrm{m}^{3}\right), \rho_{a}$ is specific heat of air $(\mathrm{J} / \mathrm{kg} . \mathrm{k}), t_{o a}$ is air temperature outside the chamber $\left({ }^{\circ} \mathrm{C}\right), t_{i a}$ is air temperature inside the chamber $\left({ }^{\circ} \mathrm{C}\right), \eta$ is ratio of the leaving air to recovered air, Ahmad et al. 2010. 


$$
Q_{\text {light }}=L I * A_{c h} * H G C
$$

where: $\boldsymbol{Q}_{\text {light }}$ energy gains from the chamber lighting (w) or (J/s), LI is light intensity $\left(\mathrm{lm} / \mathrm{m}^{2}\right), \mathrm{A}_{\mathrm{ch}}$ is champers area $\left(\mathrm{m}^{2}\right)$, HGC is heat generation coefficient of light 'depends on light source' (w/lm), Ahmad et al. 2010 and Uddin et al. 2012.

$$
Q_{\text {irrigation }}=\frac{\left(A W H_{i r}\right)\left(V_{i r}\right)}{3600}\left(C_{i r}\right)\left(\rho_{i r}\right)\left(t_{\text {oir }-} t_{i i r}\right)
$$

where: $\mathbf{Q}_{\text {irrigation }}$ energy gains through the irrigation process (w) or (J/s), $\mathrm{AWH}_{\text {ir }}$ is irrigation process number per hour, $\mathrm{V}_{\text {ir }}$ is volume of irrigation water per process $\left(\mathrm{m}^{3}\right), \mathrm{C}_{\mathrm{ir}}$ is specific density of water $\left(\mathrm{kg} / \mathrm{m}^{3}\right), \rho_{\text {ir }}$ is specific heat of water $(\mathrm{J} / \mathrm{kg} . \mathrm{k}), \mathrm{t}_{\text {oir }}$ is water temperature outside the chamber $\left({ }^{\circ} \mathrm{C}\right)$ and $t_{\text {iir }}$ is water temperature inside the chamber $\left({ }^{\circ} \mathrm{C}\right)$, Ahmad et al. 2010.

$$
Q_{\text {socking }}=\frac{\left(A W H_{s g}\right)\left(V_{s g}\right)}{3600 * 24}\left(C_{s g}\right)\left(\rho_{s g}\right)\left(t_{\text {osg- }} t_{\text {isg }}\right)
$$

where: $\mathbf{Q}_{\text {socking }}$ energy gains through grains socking process (w) or (J/s), $\mathrm{ACH}_{\mathrm{sg}}$ is socking process number per day, $\mathrm{V}_{\mathrm{aw}}$ is volume of socked grains $\left(\mathrm{m}^{3}\right)$, Csg is specific density of the socked grains $\left(\mathrm{kg} / \mathrm{m}^{3}\right), \rho_{\mathrm{sg}}$ is specific heat of the socked grains $(\mathrm{J} / \mathrm{kg} . \mathrm{k})$, $\mathrm{t}_{\text {osg }}$ is socked grains temperature outside the chamber $\left({ }^{\circ} \mathbf{C}\right)$, and $t_{\text {osg }}$ is socked grains temperature inside the chamber $\left({ }^{\circ} \mathrm{C}\right)$, Ahmad et al. 2010.

$$
Q_{\text {harvesting }}=\frac{\left(A W H_{g f}\right)\left(V_{g f}\right)}{3600}\left(C_{g f}\right)\left(\rho_{g f}\right)\left(t_{o g f-} t_{i g f}\right)
$$

where: $\mathbf{Q}_{\text {harvesting }}$ energy losses through the green fodder harvesting (w) or $(\mathrm{J} / \mathrm{s}), \mathrm{ACH}_{\mathrm{gf}}$ is socked grains number per day, $\mathrm{V}_{\mathrm{gf}}$ is volume of green fodder per process $\left(\mathrm{m}^{3}\right), \mathrm{C}_{\mathrm{gf}}$ is specific density of the green fodder $\left(\mathrm{kg} / \mathrm{m}^{3}\right), \rho_{\mathrm{gf}}$ is specific heat of the green fodder (J/kg.k), $\mathrm{t}_{\mathrm{ogf}}$ is green fodder temperature outside the chamber $\left({ }^{\circ} \mathbf{C}\right), t_{\text {ogf }}$ is green fodder temperature inside the chamber $\left({ }^{\circ} \mathrm{C}\right)$, Ahmad et al. 2010.

$$
Q_{\text {shem }}=0.75 * 1000(H P / \text { Emef }) * F u * F p * C L F_{-h}
$$

where: $\boldsymbol{Q}_{\text {shem }}$ is the sensible heat gain from electric motor, (W) or $(\mathrm{J} / \mathrm{s}), F u$ is usage factor (\%), $\mathrm{Fp}$ is part of load operating factor for motor type (\%), 
$H P$ is rated electrical horsepower of equipment motor $(1 \mathrm{~kW}=0.75 \mathrm{HP})$, Emef is electric motor Efficiency (\%), and $C L F_{-h}$ is cooling Load Factor (CLF) for given hour, Thomas 2017.

2-3-Model Solving: Equations form number (4) to (16) are considered details of all components in the right side of the equation number (3). Total value of these equations "from (4) to (16)" express on energy gain inside the chamber or energy loss outside the chamber through the sprouting and growth operations. Since, all the terms of these equation "in exception of temperature" are considered constant for each case study "Chamber". Therefore, the computing program runs one loop only to determine the value of this constant which will be kept in the computer memory. Systematically, the energy balance is determined by the program through multiplying this constant in the temperature differences at each point of measuring time.

\section{3-RESULTS AND DISCUSSIONS}

3-1-Sprouting chamber and heat balance direction: Since the ideal air temperature $\mathrm{T}_{\mathrm{db}}$ for sprouting and growth processes is $20^{\circ} \mathrm{C}$. The recoded air temperature $\mathrm{T}_{\mathrm{db}}$ outside the chamber is above the ideal temperature, as shown in table (2). Therefore, the accumulated thermal loads inside the chamber must be removed outside through air cooling process for maintaining the chamber temperature at the acceptable range " $20^{\circ} \mathrm{C}$ ". Clearly, the chamber heat balance direction is to remove the excessive heat from the inside to the outside space. Through the winter season, the differences between the recoded and the acceptable temperature $\mathrm{T}_{\mathrm{db}}$ were approximately steady at $4^{\circ} \mathrm{C}$ from 0 to $9 \mathrm{am}$, increase from 9 and $11^{\circ} \mathrm{C}$ through the period from 9 am to 15 afternoon, and decease from 11 to $4^{\circ} \mathrm{C}$ through the period from 15 afternoon to $21 \mathrm{am}$. Through the spring season, the differences between the recoded and the acceptable temperature $\mathrm{T}_{\mathrm{db}}$ approximately steady at $9^{\circ} \mathrm{C}$ from 0 to $9 \mathrm{am}$, increase from 10 and $17^{\circ} \mathrm{C}$ through the period from 9 am to 15 afternoon, and decease from 17 to $9^{\circ} \mathrm{C}$ through the period from 15 afternoon to $21 \mathrm{am}$. Through the summer season, the differences between the recoded and the acceptable temperature $\mathrm{T}_{\mathrm{db}}$ were approximately steady at $14^{\circ} \mathrm{C}$ from 0 to $9 \mathrm{am}$, increase from 14 and $22^{\circ} \mathrm{C}$ through the period from 9 am to 15 afternoon, and decease from 
22 to $14^{\circ} \mathrm{C}$ through the period from 15 afternoon to $21 \mathrm{am}$. Through the winter season, the differences between the recoded and the acceptable temperature $\mathrm{T}_{\mathrm{db}}$ approximately steady at $10^{\circ} \mathrm{C}$ from 0 to $9 \mathrm{am}$, increase from 11 and $18^{\circ} \mathrm{C}$ through the period from 9 am to 15 afternoon, and decease from 18 to $10^{\circ} \mathrm{C}$ through the period from 15 afternoon to $21 \mathrm{am}$. According to these data, this climate is considered moderate free of frost and its bad effects on the agricultural production. This result agrees with El-Ramady et al. 2013 and Hussein and Mohamed 2016.

Table (2): External air temperature $\mathbf{T}_{\mathrm{db}}\left({ }^{\circ} \mathrm{C}\right)$.

\begin{tabular}{|c|c|c|c|c|c|c|c|c|c|}
\hline & \multicolumn{7}{|c|}{ Measuring time (h) within the day } \\
\hline $\begin{array}{c}\text { Measuring } \\
\text { season }\end{array}$ & $\mathbf{0}$ & $\mathbf{3}$ & $\mathbf{6}$ & $\mathbf{9}$ & $\mathbf{1 2}$ & $\mathbf{1 5}$ & $\mathbf{1 8}$ & $\mathbf{2 1}$ \\
\hline \multirow{4}{*}{ Winter } & $R_{1}$ & 23 & 24 & 24 & 24 & 30 & 33 & 27 & 26 \\
\cline { 2 - 11 } & $R_{2}$ & 26 & 25 & 23 & 25 & 32 & 32 & 29 & 25 \\
\cline { 2 - 11 } & $R_{3}$ & 26 & 23 & 22 & 23 & 31 & 34 & 28 & 24 \\
\cline { 2 - 11 } & $\bar{Y}$ & 25 & 24 & 23 & 24 & 31 & 33 & 28 & 25 \\
\hline \multirow{4}{*}{ Spring } & $R_{1}$ & 30 & 29 & 30 & 31 & 33 & 37 & 31 & 30 \\
\cline { 2 - 11 } & $R_{2}$ & 29 & 28 & 29 & 30 & 36 & 38 & 32 & 29 \\
\cline { 2 - 11 } & $R_{3}$ & 28 & 27 & 28 & 29 & 36 & 36 & 30 & 28 \\
\cline { 2 - 10 } & $\bar{Y}$ & 29 & 28 & 29 & 30 & 35 & 37 & 31 & 29 \\
\hline \multirow{4}{*}{ Summer } & $R_{1}$ & 35 & 34 & 31 & 33 & 39 & 43 & 36 & 35 \\
\cline { 2 - 10 } & $R_{2}$ & 33 & 32 & 34 & 35 & 40 & 42 & 37 & 33 \\
\cline { 2 - 10 } & $R_{3}$ & 34 & 33 & 34 & 34 & 41 & 41 & 38 & 34 \\
\cline { 2 - 10 } & $\bar{Y}$ & 34 & 33 & 33 & 34 & 40 & 42 & 37 & 34 \\
\hline Autumn & $R_{1}$ & 29 & 30 & 31 & 32 & 34 & 40 & 34 & 30 \\
\cline { 2 - 10 } & $R_{2}$ & 33 & 29 & 30 & 31 & 35 & 37 & 31 & 30 \\
\cline { 2 - 10 } & $R_{3}$ & 29 & 28 & 29 & 30 & 33 & 37 & 31 & 30 \\
\cline { 2 - 10 } & $\bar{Y}$ & 30 & 29 & 30 & 31 & 34 & 38 & 32 & 30 \\
\hline
\end{tabular}

where: $R$ is replicates of temperature measurements, $R_{1}, R_{2}$, and $R_{3}$ are three days (selected in randomization) within each season, and $\bar{Y}$ is mean of replicates.

3-2- Values and behaviors of cooling loads: Table (3) shows vales of cooling loads (BTU/h) at eight stations through the day hours (24h) for the four seasons. The cooling load values are 3551.6 and 5741.3 (BTU/h) at 0 and $15 \mathrm{~h}$ for the winter season, 4659.2 and 6728.4 (BTU/h) at 0 and $15 \mathrm{~h}$ 
for the spring season, 5915.3 and $7735.9(\mathrm{BTU} / \mathrm{h})$ at 0 and $15 \mathrm{~h}$ for the summer season, and 4819.8 and $5741.3(\mathrm{BTU} / \mathrm{h})$ at 0 and $15 \mathrm{~h}$ for the autumn season. As a result, the minimum cooling load was found at midnight of winter season (3551.6BTU/h or 0.296 Ton or $1.396 \mathrm{hp}$ ), and the maximum cooling load was found at $15 \mathrm{pm}$ afternoon of summer season (7735.9BTU/h or $0.654 \mathrm{~T}$ on or $3.04 \mathrm{hp}$ ). These results are logic, since the outside air temperature reaches the minimum degree at 1 midnight. Irreversibly, the outside air temperature reaches the maximum degree at 1 afternoon. This result agrees with Bellos et al. 2015 and Cheng et al. 2018.

\section{Table (3): Sprouting chamber cooling loads (BTU/h):}

\begin{tabular}{|c|c|c|c|c|c|c|c|c|}
\hline & \multicolumn{9}{|c|}{ Time, hour } \\
\cline { 2 - 9 } & $\mathbf{0}$ & $\mathbf{3}$ & $\mathbf{6}$ & $\mathbf{9}$ & $\mathbf{1 2}$ & $\mathbf{1 5}$ & $\mathbf{1 8}$ & $\mathbf{2 1}$ \\
\hline Winter & 3551.6 & 3409.6 & 3267.5 & 3409.6 & 4819.8 & 5741.3 & 4489.5 & 3551.6 \\
\hline Spring & 4659.2 & 4489.5 & 4659.2 & 4819.8 & 6089.2 & 6728.4 & 4849.8 & 4659.2 \\
\hline Summer & 5915.3 & 5741.3 & 5741.3 & 5915.3 & 7367.5 & 7735.9 & 6814.6 & 5915.3 \\
\hline Autumn & 4819.8 & 4659.2 & 4819.8 & 4849.8 & 5915.3 & 5741.3 & 4819.8 & 4819.8 \\
\hline
\end{tabular}

$$
1(\mathrm{~J} / \mathrm{s})=3.412(\mathrm{BTU} / \mathrm{h}), 12000(\mathrm{BTU} / \mathrm{h})=1 \text { Ton and } 1 \mathrm{Ton}=4.716(\mathrm{hp})
$$

The remarked behavior of the cooling load curves through the four season are approximately similar, Fig. (1). The summer cooling load curve was found at the highest level. The winter cooling load curve was found at the lowest level. Both the autumn and the spring curves were found at the middle. The remarked trend of each one of the cooling load curves is approximately horizontal through the period from 0 to $9 \mathrm{~h}$, up to top from 9 to $15 \mathrm{~h}$ and top to down from 15 to $24 \mathrm{~h}$. This behavior is attributed to the same change in the outside air $\mathrm{T}_{\mathrm{db}}$. Since the outside air temperature takes the same trend from 0 to $21 \mathrm{~h}$. Therefore, stopping any operation such as "door opening, window opening, production harvesting, grain cultivation, sprouts irrigation, and production servicing" are considered critical issue in energy conservation. This must be done to prevent the outside hot air from entering to the chamber. This concept agrees with the heat transfer equations "convection case" that were mentioned in the heat transfer textbooks such as Icorpora et al. 2007. 


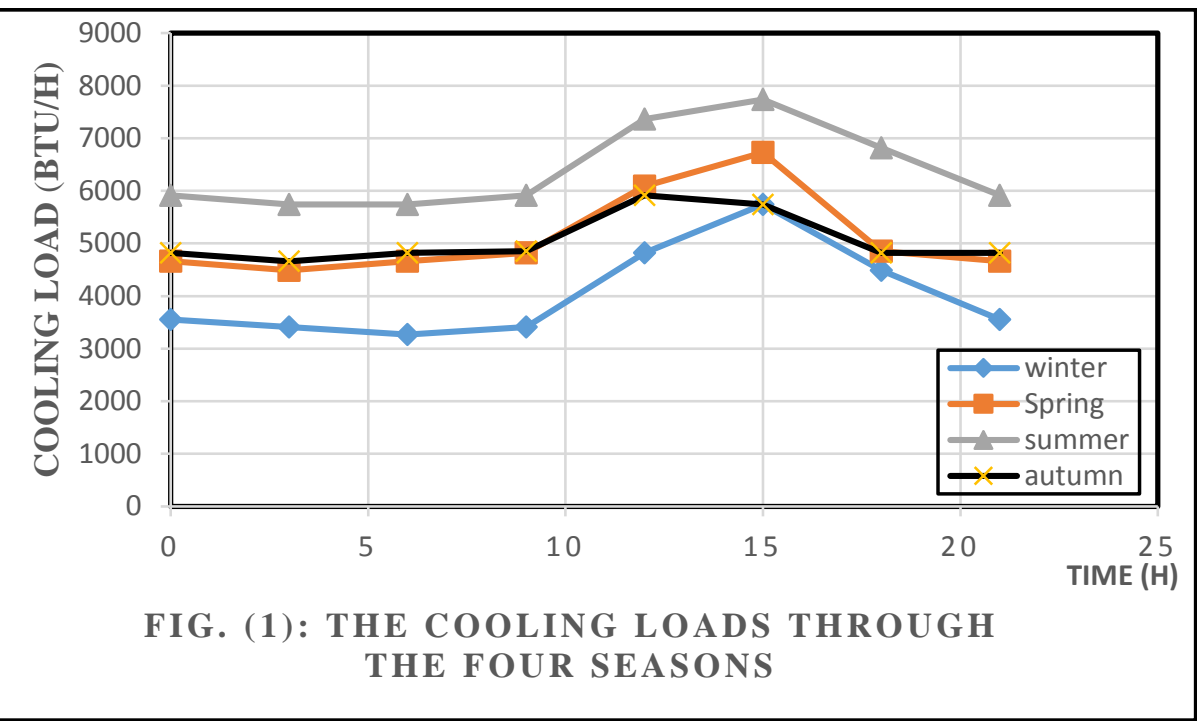

3-3-Energy conservation: Saving the consumed energy in sprouting system could be done through two stages. The first is the design and construction stage which determine types and dimensions of the building materials. The second is the engineering management stage of the technical operations inside the SGFPS.

In dealing with the first stage, table (4) shows the share percentages of heat sources through the four seasons. These percentages slightly change from season to another depending on the changes in the outside air temperatures $\mathrm{T}_{\mathrm{db}}$. Since the outside temperature is out of control, therefore it is impossible to stabilize the cooling load through the four seasons. Additionally, Fig. (2) shows values of mathematical means for share percentages of each heat source accumulated inside the chamber. Through the first stage "design and construction" the accumulated heat inside the chamber passing through walls, doors, windows, roofs, and ground could be minimized which depends on the right selection of heat transfer coefficient $\left(\mathrm{W} / \mathrm{m}^{2} . \mathrm{k}\right)$, thermal conductivity (W/m.k), thickness (m), specific density $\left(\mathrm{kg} / \mathrm{m}^{3}\right)$, and specific heat (J/kg.k) of the utilized materials. The heat production from equipment and lighting system could be minimized by using equipment and lighting system with low thermal emission factor BTU/kW. This concept agrees with the heat transfer equations that were mentioned in the heat transfer textbooks such as Icorpora et al. 2007. 
In dealing with the second stage, management of the technical operations such as "grain cultivation, production harvesting, production servicing which need to open doors and windows" have great effect on the cooling load value and energy saving. Fig. (2) shows the share percentages of heat sources in cooling load. Total values of share percentages of the technical operations which were mentioned above constitute $36.91 \%$ of the total cooling loads. These loads could be saved through management of the technical operations. Table (5) shows statistical analysis results of factorial experiment containing six treatments of operations management. The smallest cooling load was found by executing the technical operations through the third shift (12 midnight-8am) with cultivation on agricultural residues. The greatest cooling load was found by executing the technical operations through the first shift (8am-4pm) with soilless cultivation. Statistically, the difference between the smallest and the greatest cases is highly significant at $\mathrm{P} \leq 0.05$. According to the values of least significant difference LSD, the other treatments were statistically ranked between the two cases. Mathematically, the right management of the technical operations save $29.24 \%$ of the total cooling loads. This result is logic since achieving the technical operations at the first shift gives a great chance to the hot air to enter the chamber. Irreversibly, achieving the technical operations at the third shift gives a great chance to the cold air to enter the chamber.

3-4-Renewable energy source and its engineering criteria: Due to the limitation of electric energy in the conventional source, therefore using renewable sources such as solar energy in the SGFPS is obligatory. Technically, the required energy for air cooling, air ventilation, lighting, and irrigation and fertigaion loads must be covered. Mathematically, these loads could be expressed though the general criteria as follows:

$$
\begin{gathered}
E_{U A}=\left(E_{O s t}\right) / V_{C h} \\
E_{U A}=\left(E_{C l}+E_{A v}+E_{L i}+E_{I r}\right) / V_{C h}
\end{gathered}
$$

Where: $E_{U A}$ is the energy consumption per cubic meter of chamber's volume $\mathrm{kWh} / \mathrm{m}^{3}$, E Ost is sum of loads that could be operated at the same time per cubic meter of chamber's volume $\mathrm{kWh} / \mathrm{m}^{3}$. Vch is the chamber 
volume $\mathrm{m}^{3}, \mathrm{E}_{\mathrm{CL}}, \mathrm{E}_{\mathrm{AV}}, \mathrm{E}_{\mathrm{Li}}$ and $\mathrm{E}_{\mathrm{Ir}}$ are cooling, air ventilation, lighting, and irrigation loads $\mathrm{kWh}$, respectively.

Due to the limitation of the traditional sources for electric energy, therefore using renewable energy sources such as electric solar system is advisable. Technically, the electric solar system consists of electric panels, DC to Ac inverter, charge controller, and batteries. The electric solar panels are considered the corner stone in the electric solar system. Mathematically, the needed panels could be expressed as follows:

$$
\begin{array}{cc}
N P=\left(E_{A U} \times V_{C h}\right) / E_{p a} & \\
N P_{R o, A r r a y}=E_{v o} / P_{v o} & 20 \\
N R_{\text {Array }}=P N / N P_{R o, A r r a y} & 21 \\
N B=E_{A U} / B_{c a p} & 22
\end{array}
$$

where: NP is number of the needed panels "Modules", $\mathrm{E}_{\mathrm{pa}}$ is the generated energy per panel $\mathrm{kWk}, \mathrm{NP}_{\text {Ro.Array }}$ is number of panels "Modules" per each row in the panels array, $\mathrm{P}_{\mathrm{vo}}$ is voltage per panel, $\mathrm{NR}_{\text {Array }}$ is number of rows per array, NB is number of storage batteries, and $\mathrm{B}_{\text {cap }}$ is battery capacity kWh.

3-5- Confirmation by Case Study: The air cooling load is found between 4524.08 and $6393.33 \mathrm{BTU} / \mathrm{h}$ on average. The air ventilation load is found between 1474.04 to $2948.08 \mathrm{BTU} / \mathrm{h}$ in average. The lighting load is found between 1364.86 to $1706.07 \mathrm{BTU} / \mathrm{h}$ on average. The irrigation and fertigaion load is found between 2559.11 to $3412.14 \mathrm{BTU} / \mathrm{h}$ on average. Technically, the total loads which could be operated at the same time are located between $9922.09 \mathrm{BTU} / \mathrm{h}(2.91 \mathrm{~kW})$ and $14456.62 \mathrm{BTU} / \mathrm{h}(4.241 \mathrm{~kW})$ on average, Equations 17-18. Since the total volume of the chamber is $72 \mathrm{~m}^{3}$, therefore the total loads per cubic meter are located between $137.81 \mathrm{BTU} / \mathrm{h} \cdot \mathrm{m}^{3}\left(0.04 \mathrm{~kW} / \mathrm{m}^{3}\right)$ and $200.79 \mathrm{BTU} / \mathrm{h} \cdot \mathrm{m}^{3}\left(0.06 \mathrm{~kW} / \mathrm{m}^{3}\right)$ on average, Equation 17-18. The electric panels "Modules" are found in Egypt with dimensions of 99 and $164 \mathrm{~cm}$ for Monocrystalline or Polycrystalline Silicon. These panels generate electricity with Voc. of 37.5 $\mathrm{V}$ and current of 8.75 Ampere. Array of panels (3 rows 6 panels in each row) generates DC electricity $4.5 \mathrm{kWh}$ with $225 \mathrm{~V}$ and $26.25 \mathrm{~A}$, Equation 19. The needed number of solar electric storage batteries is 4 with specs of $12 \mathrm{~V}$ at $1000 \mathrm{AH}$, Equations 19-22. 
Table (4): Energy sources and its share percentages in cooling loads within the four seasons:

\begin{tabular}{|c|c|c|c|c|c|c|c|c|c|c|c|c|c|c|}
\hline & \multicolumn{13}{|c|}{ Cooling load (\%) } & \multirow{2}{*}{$\begin{array}{l}\text { Total } \\
\text { (\%) }\end{array}$} \\
\hline & $Q_{\text {walls }}$ & $Q_{\text {windo }}$ & $Q_{\text {door }}$ & $Q_{\text {roof }}$ & $Q_{\text {grou. }}$ & $Q_{\text {linear }}$ & $Q_{\text {labor }}$ & $Q_{\text {light }}$ & $Q_{\text {ventl. }}$ & $Q_{\text {irrig. }}$ & $Q_{\text {cult. }}$ & $Q_{\text {harv }}$ & $Q_{\text {shen }}$ & \\
\hline Winter & 16.51 & 2.44 & 6.59 & 9.41 & 2.77 & 4.99 & 13.33 & 15.45 & 10.55 & 8.33 & 3.85 & 2.94 & 2.84 & 100 \\
\hline Spring & 18.75 & 3.65 & 5.85 & 9.41 & 3.89 & 5.91 & 9.11 & 14.45 & 9.88 & 9.43 & 3.31 & 3.86 & 2.50 & 100 \\
\hline Summer & 20.31 & 4.81 & 4.61 & 7.05 & 2.56 & 6.36 & 7.77 & 12.85 & 7.38 & 10.51 & 4.52 & 6.79 & 4.48 & 100 \\
\hline Autumn & 19.35 & 3.63 & 5.94 & 9.41 & 3.12 & 4.43 & 9.94 & 14.45 & 8.45 & 9.95 & 3.63 & 4.85 & 2.85 & 100 \\
\hline Average & 18.74 & 3.63 & 5.74 & 8.82 & 3.08 & 5.43 & 10.04 & 14.31 & 9.06 & 9.55 & 3.82 & 4.62 & 3.16 & 100 \\
\hline
\end{tabular}




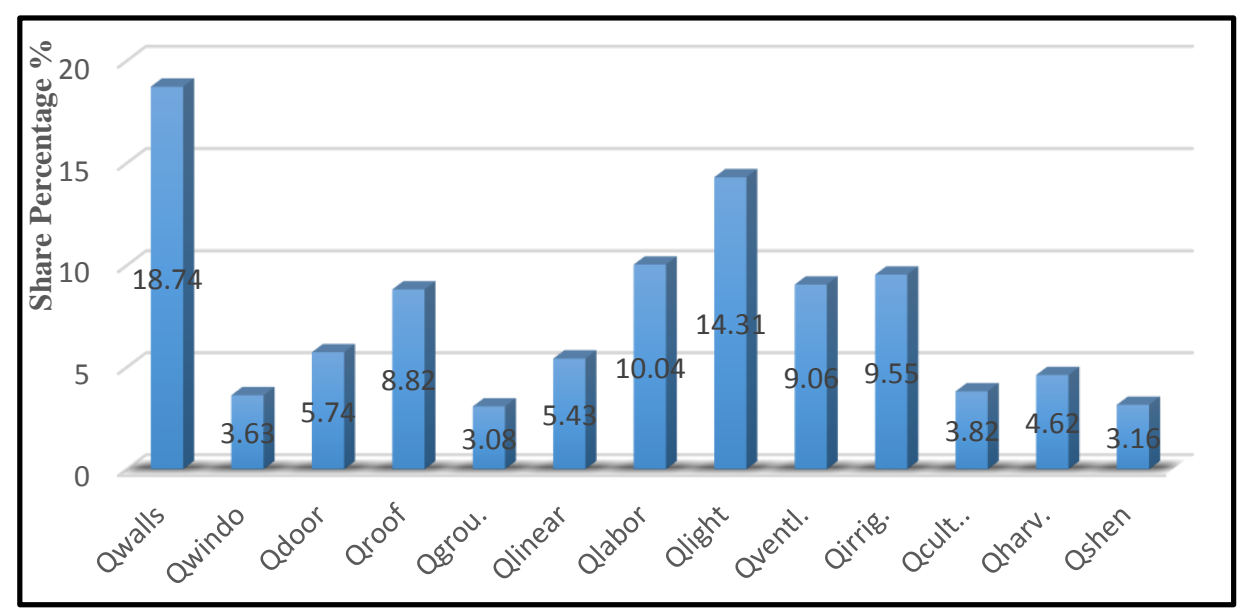

Fig. (2): Average of share percentages of the heat

Heat Sources sources in the sprouting chamber.

Table (5): Operations timing and its effect on cooling loads (BTU/h):

\begin{tabular}{|c|c|c|c|}
\hline & \multicolumn{3}{|c|}{ Timing of operations } \\
\hline$\frac{\text { Cultivation }}{\text { Systems }}$ & $\begin{array}{c}\text { First shift } \\
(\text { 8ap-4pm) }\end{array}$ & $\begin{array}{c}\text { Second shift } \\
\text { (4pm-12) }\end{array}$ & $\begin{array}{c}\text { Third shift } \\
(\mathbf{1 2 - 8 a m )}\end{array}$ \\
\hline $\begin{array}{c}\text { 1-Soilless culture } \\
\text { 6393.33 } \\
\text { Control }\end{array}$ & $5719.33^{\mathrm{c}}$ & $5130.10^{\mathrm{b}}$ \\
\hline $\begin{array}{c}\text { 2-Agric. residues } \\
\text { media }\end{array}$ & $5614.67^{\mathrm{c}}$ & $5095.46^{\mathrm{b}}$ & $4524.08^{\mathrm{a}}$ \\
\hline
\end{tabular}

where: The letters ( $a, b$ and $c$ ) indicate to means of cooling loads replicates which are homogenous and significantly different at $\mathbf{P}^{\geq 0.05}$.

\section{4- CONCLUSIONS}

For the purposes of application, the research results mentioned above could be concluded in the following points: 
1- It is necessary to use the constructed mathematical model for determining the quality and quantity of the thermal loads to achieve heat balance inside the SGFS.

2- It is necessary to select building materials with low thermal coefficients and equipment with low thermal emissions for saving energy. Since the technical specs of the building materials and electric equipment are responsible on saving $65 \%$ of the thermal loads.

3- It is necessary to finish the technical operations through the period from 1 midnight to 8 am for saving energy. Since the management of the technical operations is responsible on saving $35 \%$ of the thermal loads.

4- It is necessary to use the developed engineering criteria to determine the technical specs of the SES for reducing the reliance on the PNE.

\section{5-REFERENCES}

Ahmad, M. J.; G.N. Tiwari, A. K. Singh, M. Sharma, and H.N. Singh 2010 Heating/cooling potential and carbon credit earned for dome shaped house, IJEE Volume 1, Issue 1, 2010 pp.133-148

Andarini, R. 2014 The Role of Building Thermal Simulation for Energy Efficient Building Design Energy Procedia 47:217-226

Bambara, J. and A. Athienitis 2015 Experimental evaluation and energy modeling of a greenhouse concept with semi-transparent photovoltaics, Energy Procedia 78 ( 2015 ) 435-440

Barbosa, G. L.; F. D. A. Gadelha, N. Kublik, A. Proctor, L. Reichelm, E. Weissinger, G. M. Wohlleb and R. U. Halden 2015 Comparison of land, water, and energy requirements of lettuce grown using hydroponic vs. conventional agricultural methods, Int. J. Environ. Res. Public Health 2015, 12, 6879-6891

Bellos, E.; C. Tzivanidis, A. Kouvari, K. A. Antonopoulos 2015 Comparison of heating and cooling loads of a typical building with 
TRNSYS and EQUEST Conference: Global Conference on Global Warming (GCGW 2015), At Athens, Greece, pp:1-12 Available at: Evangelos Bellos

Burdick, A. 2011 Strategy Guideline: Accurate Heating and Cooling Load Calculations, U.S. Department of Energy Office of Scientific and Technical Information P.O. Box 62 Oak Ridge, TN 37831-0062 pp: 1-35, https://www.nrel.gov/docs/fy11osti/51603.pdf

Chen, J.; Fang Xu, D. Tan, Z. Shen, L. Zhang, Q. Ai 2015 A control method for agricultural greenhouses heating based on computational fluid dynamics and energy prediction model. Applied Energy, Volume 141, 1 March 2015, Pages 106-118

Cheng, Y.; B. Yang, Z. Lind, J. Yang, J. jia, Z. Du 2018 Cooling load calculation methods in spaces with stratified air: A brief review and numerical investigation, Energy and Buildings Volume 165, 15 April 2018, Pages 47-55

Chou K S.K., .J. Chua, J. C. Ho, C. L. Ooi 2004 On the study of an energy-efficient greenhouse for heating, cooling and dehumidification applications, Applied Energy, Volume 77, Issue 4, April 2004, Pages 355-373

Ciprian, B.; Gh. Brătucu 2014 THEORETICAL OVERALL ENERGY BALANCE IN A GREENHOUSE FOR FLOWERS 3rd International Conference Research \& Innovation in Engineering COMAT 2014 16-17 October 2014, Braşov, Romania :252-257

El-Ramady, H. R.; S. M. El-Marsafawy, L. N. Lewis 2013 Sustainable Agriculture and Climate Changes in Egypt, E. Lichtfouse (ed.), Sustainable Agriculture Reviews 12, 41 DOI 10.1007/978-94-0075961-9_2, (C) Springer Science+Business Media Dordrecht, pp: 4195

Farrell E., M. I. Hassan, R. A.Tufa, A. Tuomirantaa, A. H. Avci, A. Politanoc , E. Curcio, H. A. Arafat 2017 Reverse electrodialysis 
powered greenhouse concept for water- and energy-self-sufficient agriculture, Applied Energy, Vol. 187: Pp 390-409

Hall, M.; A. Geissler, B. Burger 2014 Two years of experience with a net zero energy balance - analysis of the Swiss MINERGIE-A® standard, Energy Procedia 48:1282-1291

Hussein, M. M. A. and Mohamed, E. E. E. 2016 Temperature Trend over Nile Delta, Egypt in 20th Century, Advances in Research 7(2): 1-14, Article no.AIR.25466

Icorpora, F.P.; Jon Wily, D.P. Bergman, T.L. Lavine, A.S. 2007 Fundamentals of heat and mass transfer, John Wily, \& Sons. Inc., 111 River Street Hobken, NJ-07030-5775, (201)746-6001.

Kempen, M.; T. Kraenzlein 2008 Energy Use in Agriculture: A Modeling Approach to Evaluate Energy Reduction Policies, The 107th EAAE Seminar "Modelling of Agricultural and Rural Development Policies". Sevilla, Spain, January 29th -February 1st, 2008: 1-15

Marucci A., A. Cappuccini 2016 Dynamic photovoltaic greenhouse: Energy efficiency in clear sky conditions, Applied Energy, Volume 170, 15 May 2016, Pages 362-376

Mesmoudi, K.; A. Soudani, B. Zitouni, P.E. Bournet, Lazhar Serir 2010 Experimental study of the energy balance of unheated greenhouse under hot and arid climates: Study for the night period of winter season, Journal of the Association of Arab Universities for Basic and Applied Sciences (2010) 9, 27-37

Mohammadi A., M. Omid 2010 Economical analysis and relation between energy inputs and yield of greenhouse cucumber production in Iran, Applied Energy, Volume 87, Issue 1, January 2010, Pages 191-196

Morken, J.: K. Fjortoft and T. Briseid 2015 AGRICULTURAL BIOGAS PLANTS - ENERGY BALANCE, NJF 25th Congress: 370-374 
Nadal, P. Llorach-Massana, E. Cuerva, E. ópez-Capel, J. I. Montero, A. Josa, J. Rieradevall, M. Royapoor 2017 Building-integrated rooftop greenhouses: An energy and environmental assessment in the mediterranean context, Applied Energy, Volume 187, 1 February 2017, Pages 338-351

Onwuka, O. 2013 Energy Heat Balance for Buildings, A Review Analysis, IJSTR, Volume 2, Issue 8:142-148

Priarone, A.; M Fossa, E Paietta and D Rolando 2017 Energy demand hourly simulations and energy saving strategies in greenhouses for the Mediterranean climate, Journal of Physics: Conf. Series 796 (2017) 012027; 1-9

Scofield, J. H. 2013 Efficacy of LEED-certification in reducing energy consumption and greenhouse gas emission for large New York City office buildings, Energy and Buildings 67 (2013) 517-524

Scognamiglio, A. and H. N. Røstvik 2012 Photovoltaics and zero energy buildings: a new opportunity and challenge for design, Published online in Wiley Online Library (wileyonlinelibrary.com). DOI: 10.1002/pip.2286

Serageeldin, A. A.; A. K.Abdelrahman, A. H. H. Ali, M. R. O. ALI, and S. Ookawara 2015 Soil Temperature Profile for some New Cities in Egypt: Experimental Results and Mathematical Model, 14th International Conference on Sustainable Energy Technologies SET 2015, 25th - 27th of August 2015, Nottingham, UK.

Song J., W. Yang, Y. Higano, X. Wang 2015 Dynamic integrated assessment of bioenergy technologies for energy production utilizing agricultural residues: An input-output approach Applied Energy, Vol. 158:Pp 178-189

Thomas, V. C. 2017 Building energy simulation and performance, E. Course, College of Architecture Illinois Institute of Technology Chicago, Illinois, USA, http://energy-models.com/advanced-training 
Trejo-Téllez, L. I.; and F. C. Gómez-Merino 2012 Nutrient Solutions for Hydroponic Systems, InTech China Unit 405, Office Block, Hotel Equatorial Shanghai No.65, Yan An Road (West), Shanghai, 200040, China, http://cdn.intechopen.com/pdfs/33765/...solutions_for_hydroponic systems.pdf

Uddin, S.; H. Shareef, A. Mohamed, M. A Hannan 2012 Harmonics and thermal characteristics of low wattage LED lamps, PRZEGLĄD ELEKTROTECHNICZNY (Electrical Review), ISSN 0033-2097, R. 88 NR 11a/2012

Vadiee A., V. Martin 2014 Energy management strategies for commercial greenhouses, Applied Energy, Volume 114, February 2014, Pages 880-888

Van Beveren P.J.M., J. Bontsema, G. Van Straten, E. J. Van Henten 2015b Minimal heating and cooling in a modern rose greenhouse, Applied Energy, Volume 137, 1 January 2015, Pages 97-109

Van Beveren P.J.M., J.Bontsema, G.van Straten, E.J.van Henten 2015a Optimal control of greenhouse climate using minimal energy and grower defined bounds, Author links open overlay panel, Applied Energy, Volume 159, 1 December 2015, Pages 509-519

Wang, X.; C. Huang and Z. Zou 2016 The analysis of energy consumption and greenhouse gas emissions of a large-scale commercial building in Shanghai, China XinWang, Advances in Mechanical Engineering 2016, Vol. 8(2) 1-8

Yadav, D. K.; A. Srivastava, A. Chauhan, G. Tripathi, A. Kumar 2017 Cooling load estimation of room, IRJET Volume: 04 Issue: 05

Zhang J., P. E. Campana, T. Yao, Y. Zhang, A. undblad, F. Melton, J. Yan 2017 The water-food-energy nexus optimization approach to combat agricultural drought: a case study in the United States, Applied Energy, Available online 


\section{الملخص العربى}

\section{نمذجة الأحمال الحرارية والحفاظ على الطاقة بمنظومات إنتاج المستتبتات مائيا}

\section{خالد خليل حجاب}

المشكلة: تعتبر منظومات إنتاج الأعلاف الخضر اء المستنبتة مائيا منظومات زر اعية صناعية كثيفة إستخدام الطاقة. حيث يتطلب الحصول على إنتاج جيد إجراء عمليات غسيل ونقع وكمر وزر اعة، ورى وتسميد، وإضاءة، وتهوية، وتبريد، وحصاد. و أن كل هذه العمليات تتم بواسطة إنة

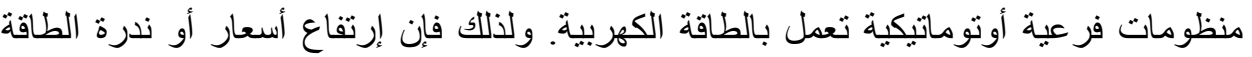
الكهربية بالمصدر التقليدى مع غياب المو اصفات الفنية لمنظومات إنتاج الطاقة المتجددة يعتبر أحد المشاكل الرئيسية فى عمليات الإنتاج.

اللهدف: ولذلك فإن الهذف الرئيسى من هذا البحث هو (1) بناء نموذج رياضى لتحديد نوعية وحجم الأحمال الحرارية، (Y) تحديد أفضل أساليب الحفاظ على الطاقة خلال مرحلتى التصميم و إدارة الإنتاج، (ب) وضع معايير هندسية تطبيقية و إستخدامها فى تحديد المو اصفات الفنية لمنظومة إنتاج طاقة متجددة لتشغيل تجهيزات غرف الإستنبات لتقليل الإعتماد على المصدر التقليدى للطاقة الكهربية.

المنهج العلمى: لتحقيق الهدف المنشود من هذا البحث تم ( (1) بناء نموذج رياضى لحساب الأحمال

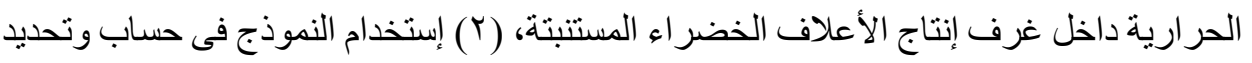
نو عية الأحمال الحرارية داخل غرفة إنتاج الأعلاف الخضر اء المستنبتة، (ب) تحديد أساليب الحفاظ

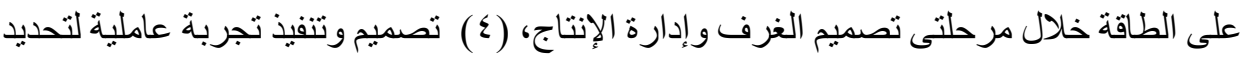
أفضل البدائل لإدارة العمليات الفنية نوفيرا للطاقة. إعتمدت العمليات الحسابية الرياضية

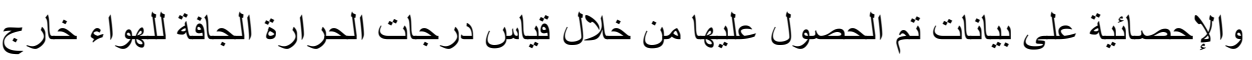
وداخل الغرفة مع الإستعانة بجداول الخصائص الحرارية والطبيعية والهندسية لمواد البناء و المعدات و التجهيزات الكهربية المنشورة على الثبكة العنكبوتية بالمو اقع العلمية المتخصصة.

النتائج: توصل البحث من خلال تحليل مخرجات النموذج الرياضى ونتائج التحليل الإحصائى

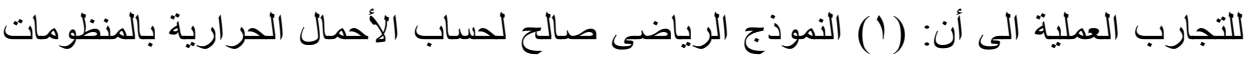

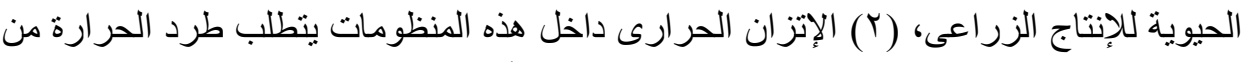

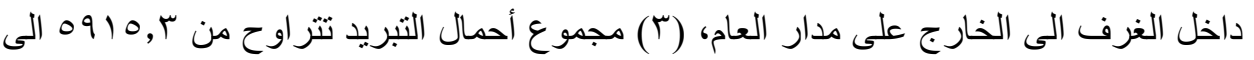

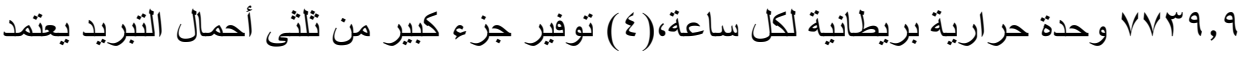

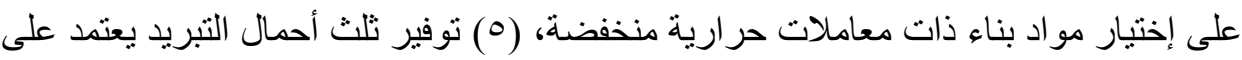
مو عد إدارة العمليات الفنية داخل الغرف، (T) خلاصة تحليل النتائج تعد معايير هندسية في تصميم منظومة الطاقة داخل غرف الإسنتبات، (V) المعايير الهندسية المستخلصة تطبيقية وتم إستخدامها فى تحديد المو اصفات الفنية لمنظومة إنتاج طاقة متجددة لتشغيل تجهيز ات غرف الإسنتبات.

*قمس الهندسة الزراعية ـ كلية الزراعة - جامعة القاهرة 


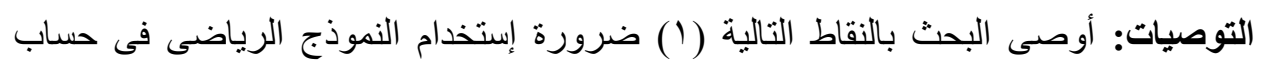

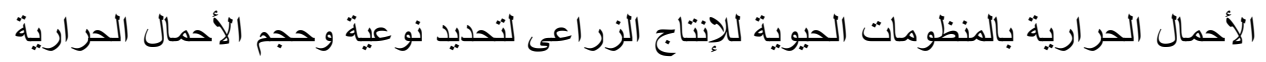

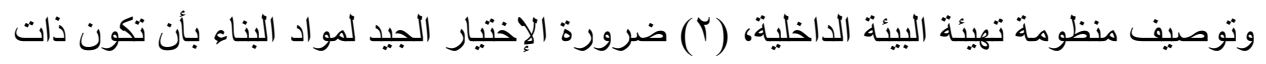

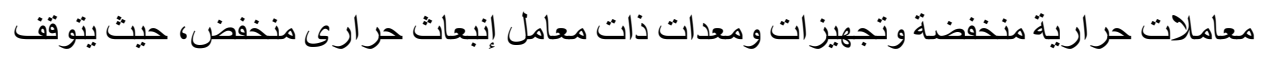

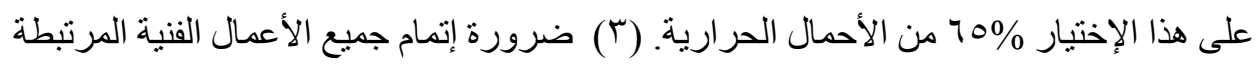

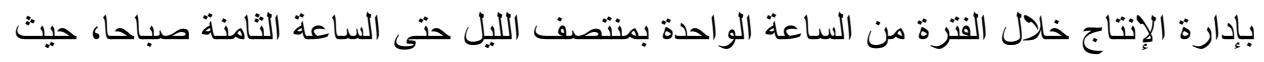

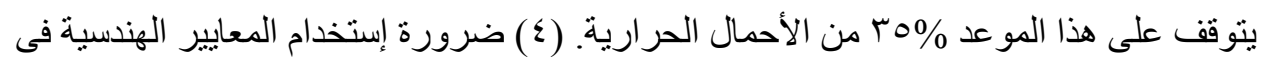

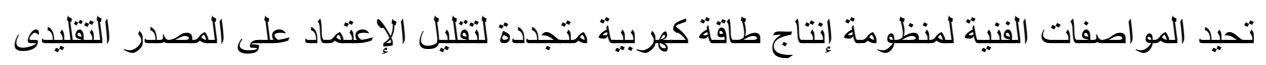
للطاقة الكهربية. 